\title{
Black economic empowerment policy and the transfer of equity and mine assets to Black people in the South Africa's mining industry
}

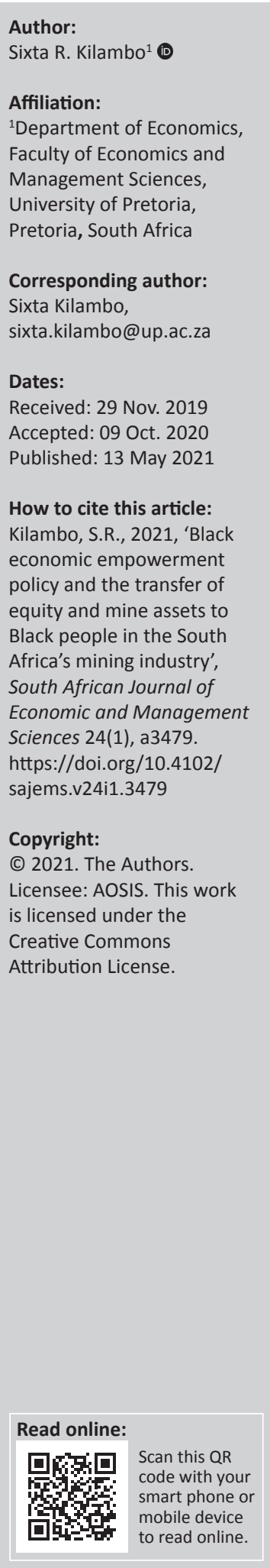

Background: The Minerals and Petroleum Resources Development Act (MPRDA) and the Mining Charter, which both came into force in 2004, required white-owned and foreign-owned companies operating in the country to transfer $26 \%$ of the value of equity ownership and ensure that historically disadvantaged persons (HDSAs) attain $40 \%$ control of mine assets. The regulations are part of the broad-based black economic empowerment (B-BBEE) policy that seeks to transform the whole economy and enable black people to participate fully in all sectors of the economy after years of exclusion under apartheid laws. The inclusion of black people in the industry started with conglomerates unbundling mining houses in the early 1990s. Elsewhere such programmes succeed through selective government intervention. The South African government instead is pursuing a hands-off approach leaving HDSAs to survive under market mechanisms, which limits HDSAs' chances of exploitation of opportunities.

Aim: To explain challenges of attaining and sustaining equity target levels and highlight the extent to which black people own equity and mine assets, explore strategies used and reveal other realities in the implementation of the policy. These aims are met by exploring the ownership structures of white-owned, foreign-owned and black-owned companies and BEE deals concluded by them between the 1990s and 2015. It was also important to learn from the experiences of countries that pursued similar policies as a means of providing knowledge and information to policymakers and the general public.

Setting: The study used a sample of 72 mining companies in South Africa operating in various mineral categories.

Methodology: This article used a qualitative approach involving both secondary and primary data. Purposeful selective sampling was used to draw from all listed mining companies with a cut-off of July 2011. The market capitalisation of these were used to estimate equity targets owned by black people. Another 16 mining companies not listed were used to explore the strategies, challenges and other realities. This required exploring changes in shareholding structures and BEE deals concluded. Face-to-face structured interviews were conducted with a total of 35 executives, top management or their representatives from 27 companies, a few members of academia and government officials between 2012 and 2014 .

Results: Targets set by the MPRDA and the Mining Charter have not been met. Thus, little equity ownership has been transferred to black people. A broad category of black people have, however, benefited from BEE deals. These include individual companies, consortiums, communities and employee ownership schemes. To avoid risks, the sellers of mine assets host black people in separate companies, special purpose vehicles and holding companies. In general, lack of capital, dilution of black shareholding, indebtedness and limited expertise to run extractive ventures successfully challenge the survival of black-owned companies. Despite these problems, a few such companies are worth billions of rand.

Conclusion: The success of empowerment policies that seek to offer selective preferences to enterprises elsewhere has depended on the government's concerted efforts. These include establishing institutions to oversee policy execution and having financial and other supports. Challenges that black-owned mining companies face indicate a call for help. Unless the government intervenes and supports them there is a danger that white-owned and foreignowned companies will completely buy back the assets once sold to black people resulting in a failure of the empowerment policy.

Keywords: Black economic empowerment; BEE; economic transformation; mining industry; South Africa; South African conglomerates; equity ownership; mine assets. 


\section{Introduction}

The transformation of the South African economy and inclusion of black people ${ }^{1}$ in all sectors of the economy was one of the main priorities of the African National Congress (ANC) government that came to power in April 1994. This process started in mining, an industry with a history of only a few white conglomerates controlling mine assets since the beginning of development of the industry in 1880s. Colonial and in particular apartheid ${ }^{2}$ laws prevented black people from owning and controlling mine assets, limiting them the provision of low-skilled labour. As a result, with the 1955 manifesto, the ANC aimed at nationalising this industry in the hope that it will benefit all the people (ANC 1955). As it prepared to take power, this idea changed and the ANC government accepted the ideology of private ownership and adherence of market forces as the main drivers of the economy. While it called for the economic transformation and, in particular, transfer of equity and mine assets to black people as a way of distributing wealth and balancing economic opportunities, the government has left this process under the whelm of market forces, limiting its successes.

Trusted to the Department of Mineral Resources (DMR), the economic transformation process in the mining industry started in November 1994 with the call to replace the 1991 Minerals Act. It took eight years of negotiations with the conglomerates (represented by the Chamber of Mines), trade unions (represented by National Union of Mine Workers) and other stakeholders. This resulted in the new mining policy - the Minerals and Petroleum Resources Development Act (MPRDA), accompanied by the Broadbased Socio-economic Empowerment Charter for the South African Mining Industry (Mining Charter) that came out in 2002 (DME 1995, 1998) and the Mining Score Card that explains the modalities of compliance. A two-year grace period was given before the full implementation of the Act and Mining Charter, which came into force in 2004. It should be noted that these policies are part of the Broadbased Black Economic Empowerment (B-BBEE), referred to shortly as BEE, policy that aims for economic transformation of not only the mining industry, but the whole economy. Hence, each other sector of the economy and each government department has its own charter guiding this process.

\footnotetext{
1.The B-BBEE Act defines the term 'black people' as a generic term that represents Indian, coloured and African citizens of the Republic of South Africa by birth or Indian, coloured and African citizens of the Republic of South Africa by birth or
decent and, together, they are referred to as 'historically disadvantaged South decent and, together, they are referred to as 'historically disadvantaged South
Africans' (HDSAs). Throughout the article I have used the term 'black people' and Africans' (HDSAs). Throughout the article I have used the term 'black people' and
HDSAs collectively, with no pejorative connotations. In the same manner, I have also HDSAs collectively, with no pejorative connotations. In the same manner, I have also
used the term 'white people' to represent the non-black population in South Africa and 'foreign-owned companies' for those who have their legal jurisdictions outside the country.

2.Translated from Afrikaans the term 'apartheid' means 'apartness', a policy introduced in 1948 by the National Party government calling for separate development of different racial groups in South Africa. Colonial and apartheid
governments passed various Acts, among them the 1913 Native Land Act which forced black people from their land, the 1923 Natives (Urban Areas) Act which forced black people from their land, the 1923 Natives (Urban Areas) Act which
prevented black people from leasing land in white areas, and the $1926 \mathrm{Job}$ Reservation Act which restricted them to few low-skilled jobs. The 1945 Native (Urban Areas) consolidation Act restricted black people from operating businesse in townships. The 1951 Bantu Authorities Act restricted black people to tribal areas. The 1963 One Man One Business Policy restricted black people from ownership of big business and prevented them acquiring shares (Feinstein 2005; Kilambo 2016).
}

To ensure the transformation of the industry and the entry of black people, the MPRDA allowed state custodianship of all mineral resources in the country and the use of licensing as a tool to transfer equity and mine assets to black people. The minister responsible for minerals resources at the time (Minister of Minerals and Energy, which changed to Minister of Minerals in 2009) has been given the power 'to grant, issue, refuse, control, administer and manage all reconnaissance, prospecting and mining rights' (see MPRDA 2.3a). Black people are offered preferences with the issuing of licenses. Holders of mining licenses referred to as old order rights, held mostly by companies owned by the incumbents - mostly white-owned companies - at the time, were required to reapply for new licenses or new order rights within five years (by 2009). The conversion and application of new licenses were tied to the inclusion of black people, referred to in the policy as 'historically disadvantaged South Africans' (HDSAs), as shareholders or business partners. A $50+1 \%$ shares by black people in a company would qualify it to be regarded as a black-owned (BEE) company while a $25+1 \%$ share by black people was referred to as a black-controlled company. The MPRDA set the target for HDSAs' equity ownership and mine asset transfer at $26 \%$ and $40 \%$ black control of mine assets in 10 years (by 2014). ${ }^{3}$

The signatory of the Mining Charter accepted the 'principle of willing seller - willing buyer at a fair market value' and if sellers are not at risk (see Mining Charter, Section 4.12). This simply implies the adherence to market forces in transactions of equity and mine assets while the government is a regulatory facilitator. The conglomerates promised to transfer R100 billion to HDSAs, which was close to $15 \%$ based on R750 billions of mine assets at the time of negotiations (Republic of South Africa 2002a, 2004). Thus, assets expected to be transferred to black people were huge. Knowing this fact, and that black people had no capital of their own and no other assets for backups, the government should have instituted proper mechanisms to help them from the start, which did not happen. As we see later, they had to rely on the sellers of equity and mine assets, who tried to avoid the risk of having them in their core assets. To assess the progress, the Mining Score Card demanded that complying companies should reach a target of $15 \%$ by 2009 , a period that coincided with that of converting licenses (Republic of South Africa 2002b).

Those who wrote about the BEE policy justified it for: deracialisation of the economy (Balshaw \& Goldberg 2008; Southall 2007), ensuring political stability (Hirsh 2005: 164), creating the middle class (Marais 2011; Mbeki 1999, 2003) and dealing with market failures created by the apartheid policy (Iheduru 2004, 2008). After all, the apartheid government also used discriminatory policies (Cargill 2010). Despite the mining industry being the first to come up with the policy,

3. Other elements of the charter require complying companies to ensure: HDSA control mine assets (participation in management), development of management, cointific, en scientifi, engineering or other skils for HDSAs, HDSAs participate in procurement chain of operations, formulation of integrated socio-economic development programmes for host communities and mobilisation of resources for major laboursending areas. 
studies that sought to assess compliance found the target levels reached low (Department of Mineral Resources [DMR] 2009; KIO Advisory Services 2010).

Critics had already flared up even before this time. They pointed to lack of success due to narrowness of beneficiaries - that the BEE policy has produced a few black moguls - dilution of black equity, fronting and the cryonic nature of BEE deals. They regarded the whole implementation process as mere window dressing (Khehla \& Reddy 2007; Mathe 2008; Mbeki 2007, Southall 2007). Beresford (2015:2-7) who looked at the cryonic nature of BEE deals at a later stage saw cronyism as a common practice in a process of class formation in post-colonial Africa. The same was witnessed in the economies of Asian Tigers, post-Soviet Russia and the oligarchic politics of Western countries where private capitalist lobbyists wielded huge influence over public officials. Ironically, using the term 'developmental patrimonialism', Booth and Mutebi (2012:381-382) argue that cronyism can act as a bridge to economic transformation and social development. This view would be a problem for some people who have been observing countless cases against cryonic leaders who try to have chunks in national resources meant to be utilised at an equal footing by all citizens, not only in South Africa but also elsewhere. Developmental capitalism is therefore a mere justification of corruption.

South Africa is not the first to use preferential policies to deal with racial disparities or for economic transformation. Over years, various states in the USA used preferential policies to seek balance in social and economic opportunities skewed against its minorities, mainly black people. Policy instruments such as affirmative employment, set-aside programmes and preferential procurement for black businesses, quotas at school colleges and universities level placements and for scholarships and other strategies were used to ensure minorities benefit from the economy at equal footing with others. Their experiences indicate that the robustness and successes of such policies depend much on the willingness of those in political power, the establishments of institutions that constantly and closely oversee and support such programmes but, mostly, on state financial support (Drake \& Holsworth 1996). Those against it, like Sowel (2004), prefer minorities to be left to struggle within the capitalist forces without government intervention. Otherwise, America's affirmative action policy prolongs racial tendencies.

Many African countries used preferential policies to ensure their citizens' inclusion in their domestic economies. This has involved the reservation of certain businesses and job placements for locals, enforcement of local content requirements on foreign companies to source from domestic and local companies, demand for equity and assets transfer to locals (see Adejugbe 1984; Andreasson 2010; Iwuagwu 2009; Ndongko 1980). Countries like Tanzania and Zambia went as far as the nationalisation and state ownership of mineral resources.
Similar to South Africa's BEE policy is Malaysia's National Economic Empowerment (NEP) programme (1970s to 1991) that sought to uplift its indigenous citizens or what it called the 'sons of the soil' or Bumiputeras. These formed part of the majority of its population groups that did not face exclusion laws per se, but were just left behind in the country's economic development trajectory. To mention a few, NEP demanded equity transfer to Bumiputeras, control of assets and affirmative employment. To support NEP, the government of Malaysia put in place a series of legislations and programmes. It revamped its education system and promoted the use of the local language (Malay) which enabled the majority to attend school and join workplaces. It used preferential quotas for school, college and university placements, scholarships and affirmative employment. The policy required $30 \%$ equity transferred to the Bumiputeras. Preferences licensing and government procurement facilities were major instruments used to enable Bumiputeras to take advantage of opportunities. The government created numerous government institutions to oversee the implementation of NEP programmes and provide a wide range of supports. Numerous parastatals created helped to support affirmative employment programmes, groom entrepreneurs and offered posts to executives and top managers, providing them with hands-on experience. Knowing Bumiputeras' lack of financial capacity, the government created a state holding company - the National Equity Corporation (Permodelan Nationale Berhad) - a vehicle company used to acquire shareholding in various private companies and warehouses on behalf of the ordinary Bumiputeras until they were ready to buy. The government established state banks and financial institutions, and bought substantial shares in private banks. Its financial capacity was important to support NEP programmes (Cargill 2010; Jesudason 1990; Lall 1996; Mandla 2006).

Japan and South Korea also used selective government interventions, not to deal with racial imbalances but for economic transformation in general (Hughes 1988; Kaplan 1972; Rhee 1994). Their cases also indicate the importance of not only political will and the creation of state institutions to oversee the implementation process, track changes, find problems and solutions but also a continual cooperation between government authorities and business. Japan's Exim Bank was crucial to offer continual financial support to local firms over a long period until they were strong enough to break into the world markets. In short, all cases explained here happened in free market settings, but indicate the importance of government's use of selective intervention in the economy and state's control of finance to support the programmes and cooperation between the state and business. In South Africa, such relationships are not harmonious. While the government accuses businesses for their lack of compliance, the businesses see the government as interfering in the working of the market. (For details of these conflicts see Bowman 2019; Makgoba 2019.)

It is true that South Africa has numerous public financial institutions, for example the National Empowerment Fund, 
established specifically to meet the funding needs of BEE beneficiaries. Its traditional Development Bank of South Africa over years played a major role in the country's industrial development. It is questionable if these together with other numerous private banks and financial institutions have the capacity to match the required $26 \%$ of mine assets to be transferred. As we see later, capital unavailability in the midst of capital intensity, inherent in extractive industries has been one of the thorny issues for black-owned companies. This article argues for the South African government to selectively intervene and support financially those who aspire to make the most of opportunities offered by the MPRDA and the Mining Charter.

The BEE policy is also happening in free market settings. The initiative was, however, started by the conglomerates (mining houses) themselves under the unbundling process in the early 1990s. These controlled a large part of the economy through pyramid structures, family ownership and crossownership that strengthened their concentration of asset ownership. As shackles of apartheid were loosening, they started unbundling their assets; in the process, they handpicked a few black people, and sold to them shares and mine assets. When the Mining Charter came into force in 2004, this process was ongoing and all of the conglomerates' transactions with black people prior to this date were recognised under the 'continuous consequences principle' clause (see Mining Charter, Section 4.7). Thus, deals at prepolicy stages gave the sellers of mine assets compliance points while black beneficiaries' wealth accumulation capabilities and experiences that made them preferred BEE partners for easily jumping on the wagon of cross-ownership and family ownership. It is the view expressed in this article that this might be a better explanation for BEE beneficiary narrowness or why only few a black people have become moguls.

\section{Methodology}

This article is descriptive and historical by nature. It uses a qualitative method involving the gathering of both secondary and primary data. Secondary sources include books, articles from journals, newspapers and magazines, company documents (annual reports, press releases and statements), financial statements, government documents (study reports, mine directories, policy documents and statements), websites and other open-access documents.

Using a selective purposeful method, a sample of 72 companies was drawn using three main criteria: (1) representation-dominant companies - Johannesburg Stock Exchange (JSE), as these make up over $80 \%$ of the industry's market value - and junior companies (non-JSE), (2) race (white-owned, foreign-owned and black-owned companies) and (3) coverage - all mine categories (platinum-group metals, gold, diamond, coal, minerals and sand aggregates). All 56 JSE-listed mining companies as per 12 July 2011 were included as the market capitalisation of these was used to estimate equity targets. Another 16 mining companies not listed on the JSE were added, as most black-owned companies are in this group. Another consideration was to include mining companies involved in BEE deals in all mining categories. In total 72 companies were used to explore strategies used, challenges and other realities. This involved tracing the ownership structures and BEE deals concluded by white-owned, foreign-owned and black-owned companies. The concentration was from the unbundling process (early 1990s) that earmarked the entry of black people to 2015 (revision of the Mining Charter). Facts that could explain the strategies used and challenges related to the study were documented. ${ }^{4}$

Structured face-to-face interviews were conducted with executives and top management of mining companies between 2012 and 2014. These included chief executive officers, chief operating officers and managing directors. In total 35 executives from 27 companies (16 from 13 whiteowned and foreign-owned companies and 19 from 14 black-owned companies) were interviewed. Further interviews were carried out with three members of academia, three government officials and one official each from the Development Bank of South Africa and the National Employment Fund who was responsible for funding. ${ }^{5}$ Thematic analysis was used which made the writing process easier.

The first section below highlights the extent to which black people own equity and mine assets. In particular it explores the ownership structure of the mining companies and deals concluded from the unbundling (early 1990s) to 2015 when the Mining Charter was revised. It also covers strategies and other realities the discussions provided. The second section focuses on licensing and meeting the targets. Targets are assessed using market capitalisation of the 56 JSE mining companies. The third section pays attention to various strategies used to accommodate black people. Explained here are the use of separate companies, special purpose vehicles (SPVs), community trusts and consortiums in concluding deals. The section also explains challenges, mostly the use of debt financing and its outcome. The last section provides conclusions and recommendations. It argues that the successes of similar policies require government support and state control of finance to afford various supports. The article recommends that the South African government needs to intervene to save BEE equity ownership and transfer of mine assets.

\section{Inside the Black Economic Empowerment honey pot}

As indicated earlier, the entry of black people started with the conglomerates' unbundling, which occurs when a company 4.The focus of the themes were: company names, percentages of shareholding owned
and exchanged, nature of the companies (consortiums, communities, employee
ownership schemes, individual companies, main companies, subsidiaries, mine projects) and deal specifications (conditions and funding models).

5.Interviews needed permissions from higher authorities and took long time. Most of the respondents decided to remain anonymous due to the sensitivity of company matters, thus their names or companies were concealed. 
with several different lines of business retains core businesses and sells off assets, product lines, divisions or subsidiaries. This important strategy may also involve mergers and acquisitions. Mergers involve two companies surrendering their stock to form one completely new company and issue new stocks. Acquisitions occur when one company buys another with cash or stocks, or a combination of the two, and absorbs the business and establishes itself as the new owner. The company that is acquired ceases to exist and its stocks are discontinued (not traded) while those of the buyer are traded. In general, poor stock performance or the need to raise capital, distribute cash, achieve cost effectiveness and improve competitiveness are the drivers of such actions (Kenton 2018).

The unbundling of South Africa's mining companies that started in the early 1990s is peculiar, mostly because of its inclusion of black people, a race that under colonial and in particular apartheid laws was forbidden from buying equity and owning mine assets but was restricted to the provision of low-skilled and unskilled labour. As a result, by the time the liberation movements were unbanned in 1990, there was not a single black owner of mining equity or assets. Conglomerates owned by white capital controlled the industry. ${ }^{6}$ These had strong family ownership, cross-ownership and pyramid structures in which, at the peak, one company will have shares in others down the line. With assets spanning all sectors of the economy, six conglomerates also widely known as mining houses, controlled the mining industry. These were Anglo American and its sister company De Beers, Rand Mines, General Mining and Finance Corporation, Anglovaal and Gold Fields (Baxter 2009; Falkena 1979; Fine and Rustomjee 1996; Nattrass 1981; Seidman \& Seidman 1977).

The mining houses performed most of their functions inhouse through their various departments. These included geological surveys, exploration, mineral extraction and processing, engineering, local and international marketing and services such as transport, mine safety, catering and cleaning. They consolidated small mines into large companies and mobilised capital and labour from local communities and neighbouring and foreign countries. In return, they kept shareholdings in such companies. Capital from mining was crucial in the expansion of the country's industrial base, which grew initially to satisfy the needs of the mines.

In the late 1980s, as it became increasingly clear that the apartheid regime was likely to collapse, the conglomerates had to find a way of surviving in the new political and economic order ahead of them. They started to unbundle their assets and engage with the liberation movements, in particular the ANC in exile (Taylor 2007). At the centre of these engagements was the issue of nationalisation, which had been the ANC's central position since the 1955 Freedom Charter (ANC 1955, 2010, 2012). This was not an option for white capital if they were to uphold their economic power. Their engagement with the ANC coincided with the unbanning of 6.Conglomeration occurs when companies own controlling shareholding in two or more other companies that might have no common business interests. the liberation movements and unbundling of mining assets that started in the early 1990s. For scholars, the conglomerates' acceptance of the BEE policy was a way of dampening nationalisation sentiments and guaranteeing their continued enjoyment of their wealth (Burton \& Hoawthorne 2007; Dansereau 2005; Iheduru 2008; Marais 2011).

The unbundling process involved a number of measures according to Malherbe and Segal (2001). These include moving some assets offshore, creating specific companies and subsidiaries in all mining categories (coal, gold, platinum and others) and creating separate companies to handle mining and non-mining assets and others to perform functions previously done in-house. They used such companies to swap and sell some of their assets and shareholdings among themselves, but sold a few to black people. They captured these happenings in a slogan 'black economic empowerment' which was then widely used in the media and townships circles even by government technocrats when calling for a greater black participation in the economy. Later the words featured in the formal policy.

Four companies have been at the forefront of unbundling. These are Anglo American (and its sister company De Beers), Rand Mines, the General Mining Finance Corporation and Anglovaal. For a better understanding of strategies used and its outcomes, this article offers details on changes in the shareholding structure of Anglo American from its unbundling and the various BEE deals emerging from the process that continued even after the coming into effect of the MPRDA and the Mining Charter. In the process, other deals concluded by other conglomerates are brought into the discussion. Captured in Figure 1 is the entire process of Anglo American's unbundling. ${ }^{7}$

Anglo American's unbundling started in 1990 when it split its De Beers Corporation into two: De Beers AG Centenary to house its non-South African assets and De Beers Consolidated Mines (Ltd) commonly referred to as De Beers to house its South African assets. As can be noted in the chart, it then created a series of companies to handle activities in various mineral categories and some used to transfer equity and mine assets to blacks. The diamond assets in the DBCM merged with those from Avmin $\mathrm{Coal}^{8}$ (Finch and Venetia Diamond Mines). By 2006, the DBCM started concluding BEE deals with blacks. These included Panahalo Investments (as lead partner in a consortium with 50\%) and ESOPs one for the 'current employees', another for identified pensioners of De Beers Group (35\%) and a Trust for Key Employee of De Beers (15\%). Panhalo Investments itself was also a consortium controlled by Panhalo Holdings. ${ }^{9}$

In the platinum-group metals, Anglo America created Amplats in 1995 to handle its platinum assets. In 2000, the

7.The numbers in circles represent percentage of shareholding exchanged.

8.Avmin Coal for coal assets and Avmin Gold for gold assets resulted from the unbundling of Anglovaal in 1999.

9.The main shareholders were: E.M. Dipico, a former premier of Northern Cape $(18 \%)$, Peotona Capital $(16 \%)$, B. Peterson (13\%), Mashishi $(8 \%)$, the Women's Trust $(17.5 \%)$, Disabled Persons Trust $(10 \%)$ and the Community Trust $(17.5 \%)$ (The Competition Tribunal Case No. 12/1m/February 2006). 


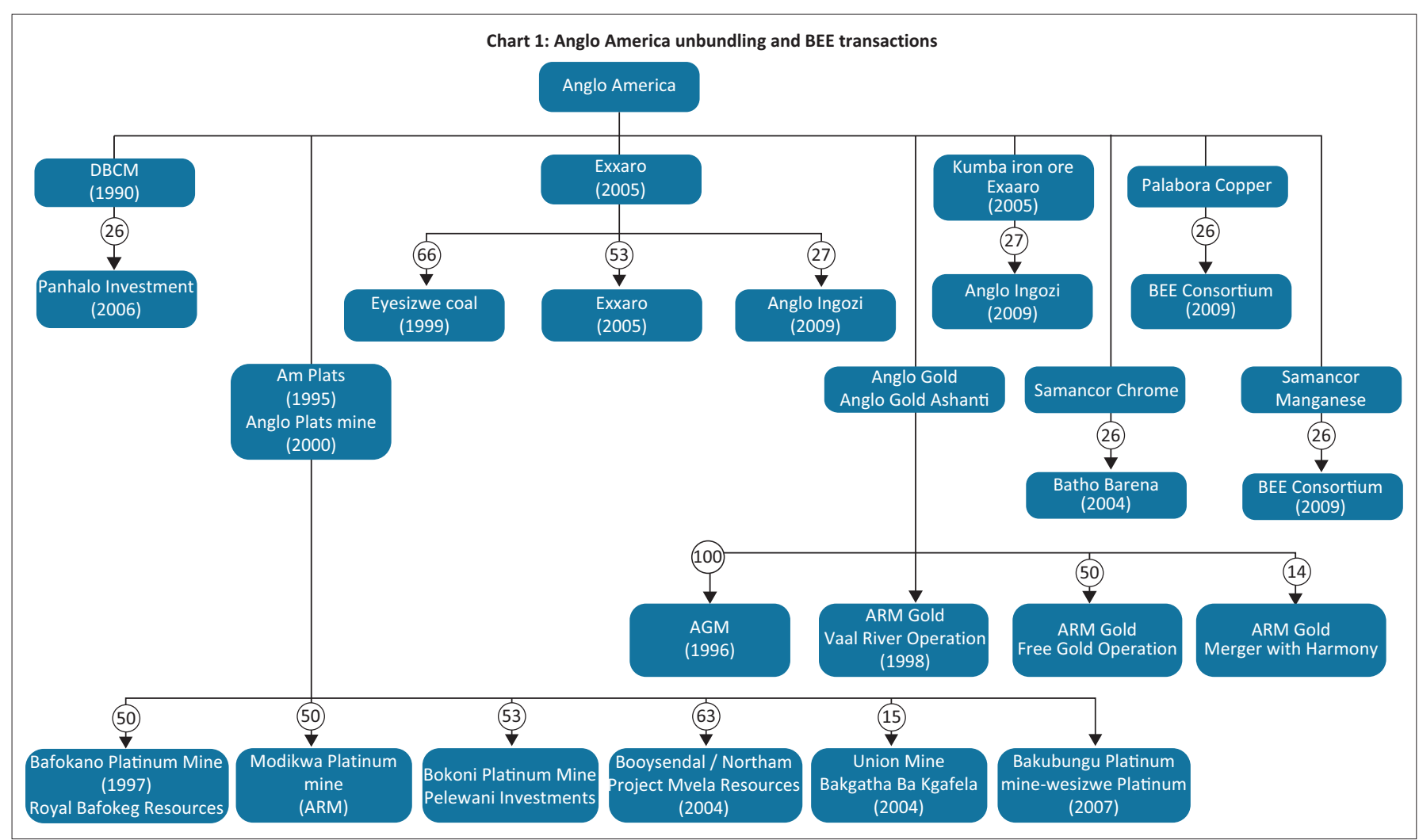

Note: Please see the full reference list of the article, Kilambo, S.R., 2021, 'Black economic empowerment policy and the transfer of equity and mine assets to Black people in the South Africa's mining industry', South African Journal of Economic and Management Sciences 24(1), a3479. https://doi.org/10.4102/sajems.v24i1.3479, for more information.

ARM, African Rainbow Minerals

FIGURE 1: Anglo America unbundling and black economic empowerment transactions.

name changed to Anglo Platinum and concluded a number of BEE deals. These include, at a mine level, the Royal Bafokeng Platinum Mine and the Royal Bafokeng Resources, which acquired a 50-50 shareholding in 1997. The Royal Bafokeng Resources is a company owned by the Bafokeng tribal community, which owns the land and used to receive royalties. These were translated into BEE shares under the MPRDA and the Mining Charter. At the Modikwa Platinum Mine it concluded a deal with the African Rainbow Minerals Consortium a subsidiary of African Rainbow Minerals $(\mathrm{ARM})^{10}$ and offered 50\% shareholding in 1999 (Anglo American 2006).

In 2004, Anglo America, which also has a major stake in the Northam mine, concluded another BEE deal. It offered a controlling shareholding of $63 \%$ at its Booysendal project to Mvelaphanda Resources, a BEE entity controlled by Mvelaphanda Holdings (under Tokyo Sekwale, an ANC stalwart once jailed at Robben Island) and Afripalm (under Lazarus Zim). In the same year, it offered 15\% shareholding to the Bakgatla Ba Kgafela, another tribal community, at its Union Mine (Anglo Platinum 2005). ${ }^{11}$ At the Bakubungu Platinum Mine, Anglo American, through its Anglo Platinum,

10.Formed by Patrice Motsepe, ARM is under the control of the African Rainbow Minerals and Exploration Investments. The Motsepe family controls $41.26 \%$, ARM Broad Based Empowerment Trust $13.45 \%$, Black Rock Inc. $10.61 \%$, Public Broad Based Empowerment Trust $13.45 \%$, Black Rock Inc. 10.61\%, Public
Investment Corporation $5.16 \%$, Fidelity Investments $4.17 \%$ and Allan Gray Investment Corporation $5.16 \%$, Fidelity Investments $4.17 \%$
Investment Council, a financial institution, 3.78\% (ARM 2010).

11.Bakgatla Ba Kgafela also controls the Moepi Group (50.1\%) and $27 \%$ shares in Boyston Investments, a subsidiary of Platmin Ltd (Canada) (Platmin 2010). retained $11 \%$ and concluded a BEE deal with Wesizwe Platinum Anglo Platinum Ltd 2008a, 2008b ${ }^{12}$ enabling it to gain control of the mine at the time, but as we see later, it lost them due to escalating debts.

Being BEE compliant comes with the benefit of being approached by other foreign-owned companies who seek to utilise mineral resources in South Africa. Anglo America seems to show the way. Through Anglo Platinum it created a SPV named Micawber 277 for its Ga Phasha Project and used it to enter into a 50-50 joint venture deal with the blackowned company Pelawan Investments. ${ }^{13}$ In 2004, Pelawan then entered into a BEE agreement with Anooraq Canada ${ }^{14}$ and offered $56.25 \%$ shares, making them the main shareholder. The transactions gave Anooraq BEE status which opened more chances of concluding other BEE deals. Anooraq then entered into another deal through its subsidiary - Plateau Resources - with Anglo Platinum's subsidiary - Rustenburg Platinum - over three projects grouped together as Bokoni Platinum Mines (Anooraq 2006, 2011).

12. Wesizwe was created in 2008; shareholders were the Bakubungu Ba Ratheo community $(25.7 \%)$, Lincoln Ngculu $(5.7 \%)$, Thuthukile Sikweiya $(5.7 \%)$ and Vunan Capital $(6.6 \%)$.

13.Pelawan Investment (Proprietary) Limited (or simply Pelawan) created the Pelawan Trust with 16 shareholders. Some of these include Figure Eight Investments $(24 \%)$, Africa Minerals Professionals $(14 \%)$, Leswika Women Investment $(10 \%)$, Africa Without Boundaries Mining (10\%) and minorities holding between $0.4 \%$ and
(Anooraq Resource Corporation pre-listing statement; 13 December 2006).

14.Anooraq, incorporated in Canada in 1983, started operating in South Africa in 1999. It created Plateau Resources as its operating company. It entered into several joint ventures with Anglo Platinum prior to the Pelawan Agreement in 2004. 
In gold, Anglo American split its Johannesburg Consolidated Investments and created Anglo Gold in 1996. The new company engaged in share exchanges with other whiteowned companies including: East Rand Gold and Uranium Company Limited, Eastvaal Gold Holdings Limited, Southvaal Holdings, Free State Consolidated Gold Mines Limited (which was known simply as FreeGold), Elandrand Gold Mining Company Limited (known as Elands Vaal), J.H. Joel Gold Mining Company Limited and Western Deep Levels. The remaining small gold mines were sold to the African Mining Group, a consortium of black-owned companies formed in 1994 under a lead partner Capital Alliance Holdings led by Mzi Khumalo. ${ }^{15}$ Capital Alliance owned 63\% shares in the Africa Mining Group. Other shareholders were Thebe Investments, Women Development Bank Holdings and Consolidated Investment Holdings. African Mining Group's foray into mining, however, lasted less than two years when it failed to raise enough finance to capitalise its mines and to pay for unpaid shares and service loans (Segeant 2006).

In 1998, Anglo Gold sold off some of its assets. One of the beneficiaries was ARMGold, a subsidiary of ARM. In this transaction, Anglo Gold entered into a contract agreement with ARMGold in 1998 over its Number One shaft of the Vaal River operations. In the contract, ARMGold would receive $40 \%$ of all the revenue for running its operation. Its success resulted in acquiring the Number Two shaft of the Vaal River operations for R10 million. In 2002, Anglo Gold sold to the same ARMGold its Free State assets through FreeGold for R2.523 million. These deals were recognised under continuous consequences principles and enabled ARMGold to bid for Avmin Gold in 2004. After acquiring Avmin Gold, ARMGold merged its gold assets with Harmony Gold, a white-owned company, acquiring 14\%. ${ }^{16}$ In 2004, Anglo Gold merged with Ashanti Gold from Ghana to form AngloGold Ashanti. The merger was also allowed under continuous consequences principle because of Anglo American's earlier transactions. To date Anglo American has completely disinvested from all gold mining in the country even its Anglo Gold Ashanti in Ghana.

Another important deal to mention involves Mvelaphanda Resources, which does not involve Anglo American per se but is important to understanding more of the strategies used. Mvelaphanda Resources, which also was a beneficiary in the platinum-group metals, had another subsidiary called Mvela Gold that had acquired 15\% of Gold Fields International Mining South Africa's (GFIMSA) ordinary shares for R4.139 billion. GFIMSA was a part of Gold Fields International Limited that moved offshore at the height of

15. Members of the Capital Alliance consortium are the National Union of Mine Workers, Mine Workers Social Investment Holdings and the South African Clothing and Textile Workers Union.

16. Harmony Gold came into existence in 1997 after the unbundling of Rand Mines in 1993 which was split into four separate companies: Harmony Gold Mining, Durban Rooderpoort Deep Gold, Crown Consolidated Recoveries and Rand Gold Resources (which became an offshore company) sanctions but came back after the end of sanctions as GFIMSA. For its South Deep Mines, it created two subsidiaries: Gold Fields Operations and Gold Fields International Joint Venture Holdings. The two were used to create a separate company - NEWCO - that acquired 100\% of ' $A$ ' shares which were equivalent to $90 \%$ of the total ' $A$ ' shares of the company that carry voting rights. Then it helped to organise numerous consortiums and offered $90 \%$ of ' $\mathrm{B}$ ' shares that carry no voting rights (equivalent to 10\%) of NEWCO's total shareholding.

Coming back again to Anglo American, the company created Anglo Coal in 1999. It immediately sought to sell off to black people the unwanted coal projects. To do this, it created a holding company known as New Coal in 2001 and placed some coals assets from Anglo American itself, Gold Fields and BHP Billiton. New Coal sold $66 \%$ assets to Eyesizwe Coal - a consortium controlled by black people ${ }^{17}$ but Anglo America retained $11 \%$ and Ingwe Coal (a subsidiary of BHP Billiton) $9 \%$. Ingwe Coal is a product of a merger of Rand Coal (from the unbundling of Rand Mines) and Trans-Natal Coal and Minerals (unbundling of General Mining and Finance Corporation).

To conclude more BEE deals, in 2005 Anglo American created two companies: a holding company known as Main Street 333 (Pty) and Exxaro. Anglo used Main Street 333, to transfer $54 \%$ to a black-owned company called Eyesizwe, $15.3 \%$ to IDC - a financial institution $-9.7 \%$ to TISO SPV, 9.7\% to Eyabantu and $11.2 \%$ to BEE Women SPV. This qualified Main Street 333 to become a BEE company and it used these qualities to acquire $53.1 \%$ of Exxaro Resources, the other company that was created by the same Anglo American. In Exxaro, Anglo American itself retained 23.7\%, and 3\% was offered to Exxaro employees and 20.2\% to minorities (publicly held) (Fauconnier \& Mathur 2008). ${ }^{18}$

In 2009 Anglo American created Anglo-Inyosi. It used this to transfer $27 \%$ shareholding to a black consortium. The members included: Pamodzi Coal (33\%), Lithemba Consortium (33\%), the Women Development Bank Holdings (19\%) and a community trust. Pamodzi Coal was itself a consortium whose main members were Pamodzi Investment Holdings (51\%), Pamodzi Coal staff (9\%), Mzana Women Investment Club (9\%) Rorisang (2.5\%) and other broad-based groupings (13\%). The Lithemba Consortium itself was made up of other smaller consortiums that included Lithemba Amalahle Mining (40\%), Initiative South Africa Resources - a women's group - $(16 \%)$, Women Executives South Africa (5\%), Mining Partners (8\%) Girls Guides (5\%) and other business associations (11\%). Two individuals acting as lead

17. Established in 1999 with Sipho Nkosi as its major shareholder; others are Daphne Nkosi, Vincent Mtambo, Kholu Motsoene and Mxolisi Ncqobo.

18. Note that in 2016 Exxaro ceased to be a BEE company as the BEE members of Main Street 333 sold their shares back to Exxaro for R3.5 billion which included R487 million debt owed to Exxaro (for the unredeemed shares). Its BEE shareholding was reduced to $30 \%$ (Mtongana 2016). In January 2017 black shareholders indicated they wanted to re-purchase their Main Street 333 Shareholding with Eyesizwe as they wanted to re-purchase their Main Street 333 Shareholding with Eyesizwe as
main shareholder with 30\% shareholding. For more detail, see Exxaro's 2018 annual report. 
partners were offered 15\%. These were Sibongile Modise (a wife of the late and former minister of defence Mr Joe Modise) and Yoliswa Balfour (Anglo American 2009a, 2009b, 2009c; Anglo Inyosi 2010). ${ }^{19}$

In other minerals (metals, manganese and copper), Anglo American has also been involved. It was part of the unbundling of ISKOR which was once partly owned by the state. In 1999 it was split into two: ISKOR Steel (which was later sold to Arcelor Mittal) and Kumba in which Anglo America acquired $66 \%$ share and transferred coal assets that were under ISKOR to Exxaro. It used Exxaro to become a BEE partner of Kumba at its Sishen and Thabazimbi mines. Anglo American was also involved in the General Mining Metals and Minerals ${ }^{20}$ and Samancor transactions. Together with BHP Billiton it took over Samancor and split into two: Samancor Manganese and Samancor Chrome. Samancor Chrome took Batho Barena Consortium (with 28\%) as its BEE partner. In 2005 it was sold to Kermas South Africa and in 2009 to the International Mineral Resources due to financial difficulties with its BEE partners. Samancor Manganese sold 26\% shares to a black consortium composed of Ntsimbintle (9\%), NCAB (7\%), IZIKO (5\%) and HMM Education Trust (5\%) (Kilambo 2016).

Anglo American with Rio Tinto jointly own the Palabora Mining Company. Together they created a separate company called Palabora Copper and used it to transfer $26 \%$ shares to a BEE consortium that includes a community trust incorporating the Makushane, Selwane, Maseke, Mashishimale and Majeje communities (10\% shares), the Palabora Copper Employee Trust (10\% shares) and the Negota consortium (6\% shares) (Palabora Mining 2010b). A similar arrangement was made by BHP Billiton and Rio Tinto with regard to Richards Bay Minerals in which they created a community trust incorporating the Sokhulu, Mbonambi, Mkwanazi and Dube communities. These together with Blue Horizon Investments acquired 26\% shareholding in Richards Bay Minerals. But apart from that, each community was offered a once-off payment of R17.5 million and a promise of R3 million annually for their social projects irrespective of whether the company declared dividends or not (Richards Bay Minerals 2011, 2012). Figure 2 shows the Dube community receiving its once-off payment.

As a principal strategist, Anglo American provides a very good example of various strategies used to incorporate black people in the mining industry. Names might have changed but their assets are spread in all mine categories. In certain mine ventures the sellers have retained 100\% shareholding. Otherwise consortiums, community trusts, employee ownership schemes and individual companies owned by black people have emerged and concluded

19.Anglo American, through Anglo Coal, has continued to sell some of its coal mines to black people.

20.This is from the General Mining and Finance Corporation which started unbundling in 1989. Its metal assets were put under general mining, gold and base metals (Samancor), platinum (Impala) and coal (Trans-Natal and Minerals). The latter merged with Rand Coal to form Ingwe Coal which sold shares to Kuyasa, a black consortium.

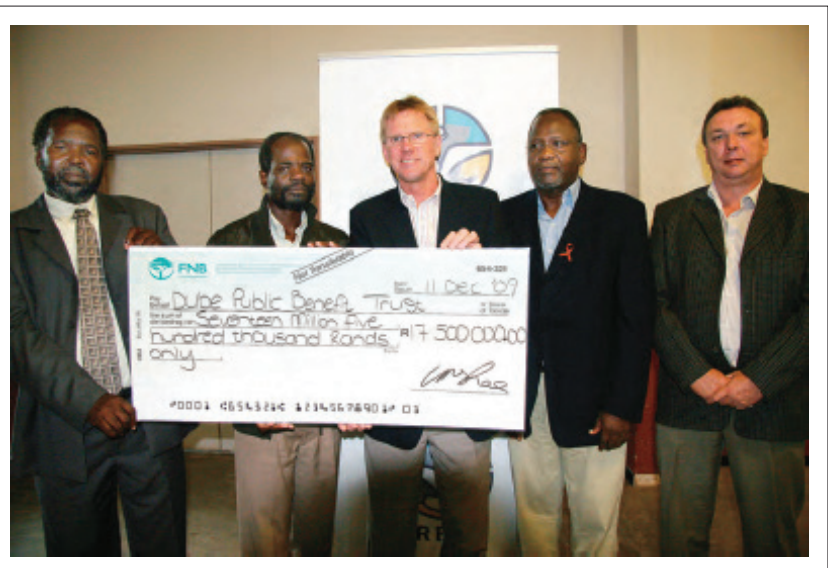

Source: Richards Bay Minerals, 2011, Annual Report, RMB, Johannesburg

FIGURE 2: The Dube community representatives receiving a once-off endowment of R17.5 million from Richards Bay Minerals.

deals with white-owned and foreign-owned companies. Before discussing more on strategies used and the final outcome of the BEE deals, it is important to highlight the degree of compliance with the MPRDA and the Mining Charter.

\section{Meeting the Minerals and Petroleum Resources Development Act and the Mining Charter targets}

One of the aims of the article was to highlight the extent to which black people own equity and mine assets. Owning equity and mine assets starts with licensing. As indicated earlier, this is was a tool of transformation under the MPRDA and the Mining Charter. Black people are given preference when issuing new licenses. It was important to explain the outcome of this. By 2012, a total of 6370 licenses were offered to black-controlled entities $(50+1 \%$ shares) which included prospecting rights $(69.8 \%$; 4446), mining permits $(20 \% ; 1274)$ and mining rights $(10 \% ; 650)$. HDSA partnerships, also referred to as black-empowered entities (those with $25+1 \%$ shares), received 5215 licenses. The majority are prospecting rights $(52 \%$; 2724$)$ followed by mining permits $(25 \%$; 1329$)$ and mining rights $(21 \% ; 1072)$. Broad-based groups, for example consortiums, communities and women groups, received 1439 licenses. These are further divided into 396 mining permits, 304 mining rights and 738 prospecting permits. It is worth noting that the remaining $50 \%$ of licenses (3289) which were issued to white-owned and foreign-owned companies with no black shareholders, imply that not every license offered was tied to having a black partner, a gap that could be used by vendors to retain some assets with $100 \%$ ownership (Kilambo 2016).

Based on the directories of operating and developing BEE companies provided by the Department of Minerals and Energy there is an indication that black-owned companies have grown from 67 in 2007 to 112 in $2010^{21}$ as indicated in Figure 3.

21.Other sources of data include Research Channel Africa $(2006,2008) ;$ Empowerdex (2004, 2009). 


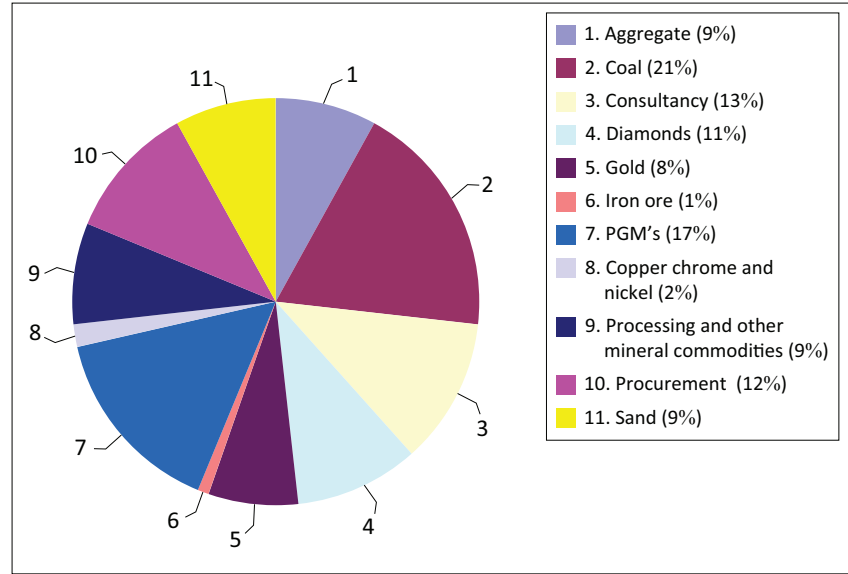

Source: Department of Minerals and Energy, 2010, Operating and developing black empowerment mining companies in the Republic of South Africa, DME, Pretoria

FIGURE 3: Number of black economic empowerment companies by commodities.

Most of these companies are in coal (21) followed by platinumgroup metals and consultancy (13). Entry of black people in coal is facilitated by a number of factors. These include a high domestic demand to feed Eskom's coal plants, preferential procurement to black people allowed under the MPRDA and simple technologies used which becomes affordable. ${ }^{22}$

Exploring the challenges of attaining and sustaining equity target levels requires checking whether a $15 \%$ (as anticipated by 2009) and a $26 \%$ target (by 2014) have been met. The norm has been to use market capitalisation of JSE-listed mining companies as data for this are readily available. ${ }^{23}$ It should be noted that the assessment of compliance targets is happening at a larger value of mining assets. From the R750 billion at the time of the signing the Mining Charter, these have grown to R2 trillion of JSE market capitalisation by 2009. The Department of Mineral Resources's Impact Assessment Report used this data indicating black people owned $9 \%$. For almost the same period and value, KIO Advisory Services (2010) indicated much lower levels $5.7 \%$ (equivalent to R97 billion of the R1.8 trillion mining assets). My own calculations based on the market capitalisation by July 2011 showed black people commanded 7.4\% (or R143.5 billion of the R1.8 trillion) as depicted in Figure 4.

Three black-owned companies owned most of this market capitalisation. These were Exxaro (R64 billion), ARM (R40 billion) and Royal Bafokeng Resources (R13 billion), accounting for $81.8 \%$. These companies have been attracting media attention, cementing criticisms that the BEE policy in the mining industry has benefited a few elites. This article has found that beneficiaries have actually broadened as BEE deals involve consortiums, community trusts, employee ownership schemes and individual companies as indicated earlier. In the following section, the article explores other

22.Seriti Resources led by Mine Teke is said to be one of black supply that by 2018 supplied about $24 \%$ of ESKOM Coal (Henderson 2018). Simple technique (bore and pillar) is also affordable to black people.

23.Market capitalisation is a total value of a firm's outstanding shares, multiplied by the market price at a time of closing business on a particular day. JSE market capitalisation instruments include ordinary shares (these carry rights to dividend capitalisation instruments include ordinary shares (these carry rights to dividend
and rights to votes), preference shares, debentures and depository receipts. They and rights to votes), preference shares, debentures and depository receipts.
also include exchange-traded funds, warrants and options (Treasury 2017).

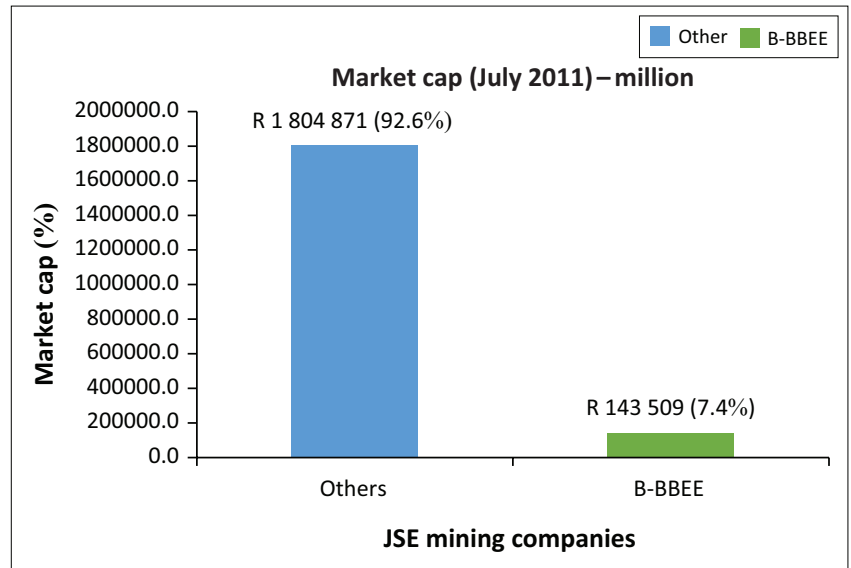

Source: Kilambo, S.R., 2016, 'Black economic empowerment and change in ownership and control in South Africa's mining industry', PhD thesis, University of Edinburgh, Edinburgh FIGURE 4: Market capitalisation by value of listed mining companies (July 2011).

realities of deals concluded, in particular strategies used and outcomes in order to shed more light.

\section{Strategies used and outcomes}

Earlier the article discussed in detail the structure and BEE deals concluded by Anglo American. The company was at the centre of the unbundling, merging, swapping, selling and buying shares and assets among the other conglomerates. In this section, it is important to elaborate on the strategies in order to understand more of their impact and the nature of challenges encountered.

The first strategy is the creation of separate companies, SPVs, holding companies and trusts to host black shareholders or partners. Although these are normal company strategies worldwide, in this context they help vendors and sellers to retain the controlling shares exclusively in their core assets and dispose the minors to black people. Companies like New Coal Main Street 333 (Pty) and Exxaro mentioned above are among those created for such purposes. The separate companies created allow companies to choose which mine assets to retain $100 \%$ ownership of (excluding black people) and which to dispose of, or offer some percentage to black people. This is clearly shown by Anglo Coal and Anglo Platinum's dealings discussed above. For example, in the platinum belt, Anglo Platinum decided to offer shares at mine level incorporating also the communities. Since they initiated the process, the conglomerates were free to handpick a few black beneficiaries and offer shareholding or mine assets repeatedly. As the few handpicked black people accumulated wealth and acquired experience, they became a strategic choice in other transactions even when the MPRDA and the Mining Charter came into effect. ARM, Shanduka and Mvelapanda Resources are good examples. Scholars like Thomas Picketty (2010) who looked at the challenges of dealing with inequalities argues that those with wealth have the means to invest more in new wealth creating ventures, widening the gaps in wealth inequality.

Apart from individual companies - some with controlling family shareholding - the trend has been using consortiums. 
A string of black people join a consortium and smaller consortiums join larger ones and conclude deals with whiteowned and foreign-owned companies and even black-owned companies. The dealings in consortiums depend much on a lead partner. This is a person usually offered a larger shareholding, but trusted to act as a go-between for consortium members and vendors. From interviews conducted with executives of white-owned, foreign-owned and black-owned companies, it became clear that most preferred are those that seem to be known around their communities or groups and have the ability to organise, provide guidance, coordinate and negotiate deals with the vendors. Mostly importantly are those with political connections, explaining the cryonic nature of BEE deals. This has become one of the sources of criticism..$^{24}$ The executives of black-owned companies that have acted as lead partners complained of the heavy burdens (in terms of finance, management duties and time) that they have to shoulder as they try to meet the expectations of the vendors and consortium collaborators. The white-owned companies expect them to act as a bridge to reach a pool of their black brothers or sisters aspiring to be BEE shareholders (Kilambo 2016). It is believed here that such differences in the expectations call for government's guidance for conducting relationships in consortiums.

The second strategy involves using community trusts. Thus, large and small trusts have emerged to conclude BEE deals. This is one of the requirements of the MPRDA and the Mining Charter and an indication that mining companies cannot easily bypass communities in which their mining activities take place. Large communities like Royal Bafokeng, which has a strong administrative structure, have entered into partnerships with mining companies operating in their areas and converted their royalties to shareholding. There are, however, different contractual arrangements for smaller communities in which some are offered once-off payments as in the case of the Dube community shown earlier. In informal conversations with a few leaders of smaller communities, I found that they have little knowledge of the value of the BEE shareholding allocated to them, and no clear demarcation of expenditures on projects offered under company social responsibilities and those from dividend payments received from BEE shareholding. This was also observed by Busacca (2013) and Rajak (2012) who warned that complying companies tend to mix their BEE compliance obligations with those that fall under corporate social responsibilities. I also believe what Cargill (2010) says: that the government needs to offer guidance on communities' involvement in mining companies operating in their areas and establish permanent administrative structures. Without such, communities are likely to be manipulated by mining companies.

24.The list of politically connected individuals is long. It includes President Cyri Ramaphosa who through Shanduka Resources benefited from many mining BEE deals, including Kangra Coal, Pan African Resources, Shanduka Coal, Lace Diamonds nd Assore. The list further includes Patrice Motsepe of ARM whose two sisters are married to President Ramaphosa and Jeff Radebe (the longest serving Minister to date whose wife Bridget is a major shareholder of Makau Mining), and Tokyo Sekwale, the first premier of Gauteng and Minister of Settlements under Zuma's first term.
From the literature and interviews conducted with executives of mining companies for this article, serious issues were highlighted. Black people lack finance for acquiring shares, capitalising mine ventures and covering operational costs. Their situation is worsened by them lacking collateral, which is important in sourcing funds from financial markets. Thus, they depend on sponsorship from vendors of mine assets. To avoid the risks of transferring assets to cashless black people, sellers use not only separate companies to host black people, but also debt financing. Black beneficiaries are allocated free shares without putting money down in the first place. With the sponsorships and guarantee from vendors, willing financial institutions accept such deals with the expectations that shares will be redeemed later through dividends or external finance. (Recently this was also noticed by Nhasengo 2016.) Without payments, debts accumulate. The 1998 financial crisis saw black shareholding being resold back to vendors.

The conditions for BEE deals include lock-in clauses and ring fencing. Lock-ins prevent black-owned companies entering into deals to trade their shareholding until a specified agreed date and ring-fencing gives first option to vendors to buy back their shares when black shareholders are forced to sell. The outcomes of all these are share dilution, liquidation or total exit from BEE deals. A few examples below will suffice to explain the outcome of such strategies and their results.

The first is Mvelaphanda Resources, mentioned earlier: its main shareholders are Mvelapanda Holdings and Afripalm Holdings which had also acquired $63 \%$ of Northam Platinum in a BEE deal with Anglo Platinum as explained earlier. Bound by a lock-in clause, Mvelapanda could not quit the deal until the end of the agreement. Mvelapanda's debt accumulated to R5.5 billion by 2010 and it was under increasingly pressure to settle it. Moreover, it was accused of being in a pyramid structure because it controlled over $50 \%$ of Northam and received $75 \%$ of its income from Northam. To break the pyramid, Northam acquired the entire Mvelaphanda Resources' issued ordinary shares. This implies Mvelaphanda Resources ceased to exist so its lock-in-clause was no longer binding. Its shares were returned to its original shareholders, which were Mvelapanda Holdings and Afripalm Holdings. Free from the lock-in-clauses, Mvelaphanda Holdings and Afripalm Holdings were now able to strategise on how to get out of their debts. Mvelaphanda Holdings decided to sell 12.2 million shares in Northam to the Eurasian Natural Resources Corporation - a foreign-owned company - for R2.2 billion. Afripalm also decided to sell some of its shares in Northam to the Public Investment Corporation to meet its debts with Nedbank. Consequently, the two companies' BEE shareholding in Northam was diluted to a mere $22 \%$ (Mvelaphanda Holdings $10.6 \%$ and Afripalm Holdings 11.5\%) (see Northam 2010, 2011). Mvelaphanda Resources had another subsidiary called Mvela Gold that had acquired $15 \%$ of GFIMSA's ordinary shares for R4.139 billion. It was then forced to sell 11 million of these shares in order to 
minimise debts. Consequently, Mvelapanda's Resources shareholding in GFIMSA was reduced to only 3\% (Gold Fields 2010).

The second is Optimum Coal Mines. ${ }^{25}$ By the time of its listing on the JSE in 2010, black people controlled $61 \%$ equity through Optimum Coal Holdings. Accumulated debts from the purchase of the mines and operating costs forced black shareholders to sell to Xstrata Glencore (a new foreign-owned company that operates through its subsidiary, Purito BV) and Lexshelf (a company connected to Cyril Ramaphosa). Together they bought $71 \%$ of Optimum Coal equity (Villa 2013). Optimum Coals's capital shortfalls worsened when in 2015 Eskom imposed a fine of R2 billion on the company for supplying substandard coal and halted advance payments for the coal deliveries. The only option was for Optimum Coal Mines, together with Optimum Coal Holdings, to be sold. The buyer was Tegeta Resources, which is part of Oakbay Investment. Its main shareholder (with 29\% equity) is the Gupta family. The manner in which Optimum Coal assets were sold to Tegeta Resources prompted an investigation of state capture against the Gupta family by the Public Protector in 2016. The report released in October 2016 concluded that the conduct of Eskom was to blame for forcing Optimum Coal Mine and Optimum Coal Holdings into business rescue and financial stress, leading to a takeover by Tegeta Resources. This was clear when one considers the fact that Eskom paid in advance R659 million to Tegeta Resources but used this to pay for the purchase of the two entities (Public Protector 2016). ${ }^{26}$

The third is Incwala Resources, another black-owned company created in 2004, which acquired $18 \%$ shares in a white-owned company named Lonmin at its Western and Eastern mines and 26\% equity in Akanani Platinum Project. By 2010, Incwala was unable to service its debts. Receiving no financial returns prompted its black shareholders to opt out of the BEE deals. To avoid losing its BEE status, Lonmin had to find another black partner. It got hold of Shanduka Resources (linked to President Ramaphosa). Lonmin as a vendor had to provide a loan to Shanduka Resources of R2.5 billion for five years. To cover this loan, Lonmin placed 10 million shares (equivalent to $5 \%$ of its issued shares) with international investors (Lonmin 2010, 2011).

The fourth is Wesizwe Platinum, a once JSE-listed blackowned company, that had to source funds in international markets to develop its Bakubungu Mine where it was a major shareholder. In 2008, it entered into an agreement with the Jinchuan Group from China. In a series of negotiations that followed, Jinchuan acquired $45 \%$ equity of Wesizwe Platinum Hall 2010 for US\$200 368 292, provided a debt facility for

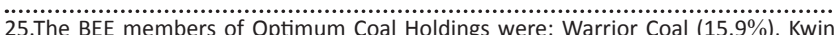
Mining Investments $(10.33 \%)$, employee trust $(9.93 \%)$, community trust $(9.93 \%)$ Micsay Investments $(7.55 \%)$, Monkge Coal Investments $(5.28 \%)$ and Mobu Resources (2.26\%) (Optimum Coal 2009, 2010).

26.The Zondo Commission is currently investigating how the Gupta family came to capture the state under the Zuma presidency for its own benefit.
US\$650 million and took over the management of the mine. Thus, Wesizwe lost control of its mine assets, its shareholding diluted to a mere $16.33 \%$ and its BEE status was lost. Its unpaid-for shares were housed in Micawber 809 SPV (Wesizwe Platinum 2011).

Issues of lack of capital are not isolated from other problems that black-owned companies face. From interviews with the executives of black-owned companies, it was revealed that not only lack of capital, but also limited knowledge of mineral extraction activities, poor technological usage, difficulties in accessing land and export markets limit their successes. Most of those interviewed in the coal sector mentioned that the extractive industry is capital intensive and it is difficult to get funding. More knowledge about technology and extractive activities is needed. Before exporting, for example, one needs washing and other preparations, but facilities are controlled by older, larger companies. As newcomers, black-owned companies have to cooperate and use their facilities if they want to participate in export markets. When asked about procurement facilities offered under the BEE policy, they indicated that with limited capital and operational capacity, they also cannot easily meet their supply quotas.

It is worth noting the strategies used by some emerging BEE companies to stay in operation. From interviews with Clyde Johnson, chief executive officer of Sedibeng Mining, and Nchakha Moloi of Motjoli Resources, ${ }^{27}$ the two companies acquire prospecting and exploration licenses upon finding potential deposits; they enter into joint ventures with other mining companies to develop mining assets to a bankable stage and sell them. The acquired cash is used to develop other assets (Kilambo 2016). These kinds of strategies are encouraging and need more investigation. It is believed that these are companies to which the government can selectively offer support.

It is also important to look at government's strategies. ${ }^{28}$ This has concentrated on specifications of the policy that do not reflect putting in place support mechanisms despite being aware of problems that black people experience in the mining industry. In its suggestions to the amendments to the Mining Charter, first the government retained the $26 \%$ target. Secondly, in its frantic move to enable black people attain control, it called for complying companies to allow black people participate fully in annual general meetings and required them to have voting rights. The compliance of this is questionable taking into consideration the dilution of black shareholding and the use of nonvoting shares allowed in concluding BEE deals. Thirdly, the government is calling for complying companies that are in

27. Motjoli Resources is a $100 \%$ black-owned junior mining and exploration company. Mr Nchakha Moloi and Ms Nonkqubela Mayatula founded it in 2004. Moloi is a geologist who gained experience as chief executive officer of Mintek, Alexkor and South African Mining Development and as deputy director general at the South African Mining Development and as deputy director general at the and was instrumental in providing input for the MPRDA and the Mining Charter.

28. Note that the 2002 Mining Charter and its Amendment in 2010 ended in 2015. The new Minister of Finance $\mathrm{Mr}$ Tito Mboweni announced the withdrawal of the new Minister of Finance Mr Tito Mboweni announced the withdrawal of the
MPRDA Amendment Bill in his mid-term budget review on 24 October 2018, resulting in policy uncertainty (Treasury 2018). 
partnership with BEE partners to provide them with cash flow throughout their deal term, regardless of whether they made a profit or a loss. Again, it is questionable if such a call supports profit motives which private firms strive for and it is not certain whether such cash flows will be used to redeem their shares. Fourthly is the continuous consequences principle which failed to scrap the clause requiring ongoing compliance. ${ }^{29}$ Their strategy is thus concentrated on policy specifications and not supporting black entrepreneurs.

\section{Conclusion}

In conclusion, black equity stood at only $7.4 \%$ (or R143.5 billion of the R1.8 trillion) of JSE market capitalisation by 2011. This was a far cry from the $26 \%$ expectations of the 2002 MPRDA and the Mining Charter. Black people have been trying hard to exploit opportunities provided by the new mining regulations signified by a broad category of beneficiaries. These include individual companies, consortiums, community trusts and employee ownership schemes and few of these are worth billions of rand. While part of the explanation for low compliance levels is the unexpected expansion of the value of assets from R750 million in 2002, the government carries the blame. The thorny issue is lack of finance in the face of various problems (lack of expertise, collateral, access to land in mineral-rich areas and others) that black people experience. The government leaves them to struggle within the market forces. White-owned and foreign-owned companies were expected to freely comply to transfer $26 \%$, which is a huge value, to help with funding, collateral and other support. It is not surprising that debt financing and the use of conditions have been preferred by sellers. All these have led to growing indebtedness, dilution of shareholding and black people selling their equity and mine assets back to sellers.

The profundity of such realities explained in this article better helps explain challenges of attaining and sustaining target levels, and the limitations of black people's utilising opportunities offered by the policy. Experiences from similar policies elsewhere indicate their successes depended on direct government enforcement through governmentcreated institutions selectively and continuously offering various types of support and mostly state finance. It is suggested here that a new strategy for the implementation of the MPRDA and the Mining Charter is needed. In particular, instead of the hands-off approach and the concentration on changing the specifications of the policy, the government needs to be proactive. In particular it should selectively use incentives and provide reliable sources of finance to capitalise mining projects, cover operational costs and offer training in requisite skills. Furthermore, the government should move away from voluntary adherence to regulations and effectively use its state institutions to continuously oversee, enforce and monitor the implementation, track the changes in the composition of ownership, unlock problematic areas and find solutions. In short, it should nurture its pool of black entrepreneurs or otherwise it should not expect them to survive and the BEE policy to succeed in the mining industry.

\section{Acknowledgements Competing interests}

The author has declared that no competing interest exist.

\section{Author's contribution}

S.R.K. declares that she is the sole author of this research article.

\section{Funding information}

This research received no specific grant from any funding agency in the public, commercial or not-for-profit sectors.

\section{Ethical considerations}

This article followed all ethical standards for research without direct contact with human or animal subjects.

\section{Data availability}

The authors confirm that the data supporting the findings of this study are available within the article.

\section{Disclaimer}

The views and opinions expressed in this article are those of the author and do not necessarily reflect the official policy or position of any affiliated agency of the author.

\section{References}

Adejugbe, M., 1984, 'The myths and realities of Nigeria's business indigenization', Development and Change 15(4), 577-592. https://doi.org/10.1111/j.14677660.1984.tb00197.x

African National Congress, 1955, Freedom charter, viewed 10 May 2009, from http:// africanhistory.about.com/od/apartheid/a/FreedomCharter.htm.

African National Congress, 2012, Maximising the developmental impact of the people's mineral assets: State intervention in the mineral sector, ANC Policy people's mineral assets:
Institute, Johannesburg.

African National Congress Youth League, 2010, 'Towards the transfer of wealth to the ownership of the people as a whole: A perspective on nationalization of mines, discussion document', Umtambulo 33.

Andreasson, S., 2010, 'Confronting the settler legacy: Indigenization and transformation in South Africa and Zimbabw', Political Geography 29(8), 424-433. https://doi.org/10.1016/j.polgeo.2010.10.003

Anglo Platinum Limited, 2005, Annual report, Anglo Platinum Limited, Johannesburg. Anglo American Plc., 2006, Transformation report (BEE), Anglo American, Johannesburg. Anglo American Plc., 2009a, Fact book 2008/9: Coal, Anglo American, London.

Anglo American Plc., 2009b, Fact book 2008/9: Platinum, Anglo American, London. Anglo American Plc., 2009c, Fact book 2008/9: Base metals, Anglo American, London. Anglo American Plc., 2019, Fact book 2018/0191, Anglo American, London.

Anglo Inyosi, 2010, Annual report, Anglo Inyosi, Johannesburg.

Anglo Platinum Limited, 2008a, Annual report, Anglo Platinum Limited, Johannesburg. Anglo Platinum Limited, 2008b, Meaningful and sustainable empowerment in the platinum industry, Anglo Platinum Limited, Johannesburg. 
Anooraq Resources Corporation, 2006, Pre-listing statement 13 Dec 2006, Anooraq, Johannesburg.

Anooraq Resources Corporation, 2011, Management discussion and analysis of financial conditions and results of operations for the period ended March 2011 Anooraq, Johannesburg.

African Rainbow Minerals, 2010, Annual report, ARM, Johannesburg.

Balshaw, T. \& Goldberg, J., 2008, Broad-Based black economic empowerment, BEE score card, Human and Rousseau, Cape Town.

Baxter, R., 2009, Brief overview of the mining industry, Chamber of Mines, Johannesburg.

Beresford, A., 2015, 'Power, patronage and gatekeeper politics in South Africa', African Affairs 114(455), viewed 05 December 2015, from http://afraf.oxfordjournals.org/ content/early/2015/02/03afraf.ac.

Booth, D. \& Mutebi, F.G., 2012, 'Developmental patriamonialism? The case of Rwanda', African Affairs 111(444), 379-403. https://doi.org/10.1093/afraf/ads026

Bowman, A., 2019, 'Black economic policy and state business relations in South Africa: The case of mining', Review of African Political Economy 46(160), 223-245. https://doi.org/10.1080/03056244.2019.1605587

Burton, A. \& Hoawthorne, S., 2007, 'SA's booming middle class', South Africa Information, 24 May, Johannesburg.

Busacca, M., 2013, 'Corporate social responsibility in South Africa's mining industry: Redressing the legacy of apartheid', senior thesis paper 632, CMC, Cape Town.

Cargill, J., 2010, Trick or treat: Rethinking black economic empowerment, Jacana Media, Johannesburg.

Competition Tribunal of South Africa, 2006, Panahalo Investments (Pty) Ltd and De Beers consolidated mines holdings, Case doc. 12/LM/Feb. 06, Competition Tribunal, Pretoria.

Dansereau, S., 2005, 'Win-win or new imperialism? Public-private partnerships in African mining', The Review of African Political Economy 32(103), 47-62. https:// doi.org/10.1080/03056240500121024

Department of Minerals and Energy, 1995, Discussion document on a minerals and mining policy for South Africa, DME, Pretoria.

Department of Minerals and Energy, 1998, White paper: A minerals and mining policy for South Africa, DME, Pretoria.

Department of Mineral Resources, 2009, Mining Charter Impact Assessment Report, Government Printers, Pretoria.

Department of Minerals Resources, 2010, Operating and developing black empowerment mining companies in the Republic of South Africa, DME, Pretoria.

Drake, W.A. \& Holsworth, R.D., 1996, Affirmative action and the stalled quest for black progress, University of Illinois Press, Chicago, IL.

Empowerdex, 2004, The state of black economic empowerment in the mining sector Empowerdex, Johannesburg.

Empowerdex, 2009, A summary of the BEE transactions in the mining sector 20042008, Empowerdex, Johannesburg.

Exxaro, 2010, Integrated annual report, Exxaro, Johannesburg.

Exxaro, 2011, Annual report, Exxaro, Johannesburg.

Exxaro, 2012, Annual report, Exxaro, Johannesburg.

Exxaro, 2018, Annual report, Exxaro, Johanesburg.

Falkena, H.B., 1979, The South African state and its entrepreneurs, A. D. Bonker Publisher, Cape Town.

Fauconnier, A. \& Mathur, H.B., 2008, 'Black economic empowerment in the South African mining industry: A case study of Exxaro limited', South African Journal of Business Management 34(4), 1-14. https://doi.org/10.4102/sajbm.v39i4.567

Fine, B. \& Rustomjee Z., 1996, The political economy of South Africa: From minerals energy complex to industrialization, West View Press, Cape Town.

Feinstein, C., 2005, An economic history of South Africa, Cambridge University Press, Cambridge.

Gold Fields, 2010, Annual report, Gold Fields, Johannesburg.

Hall, R., 2010, 'A political economy of land reform in South Africa', Review of African Political Economy 31(100), 213-227. https://doi.org/10.1080/0305624042000262257

Henderson, R., 2018, 'BEE mining tussle rages on despite court ruling', Sunday Times/ Business, 08 April, p. 1.

Hirsh, A., 2005, Seasons of Hope: Economic Reform under Mandela and Mbeki, University of KwaZulu-Natal Press, Scottsville.

Hughes, A., 1998, Achieving industrialization in East Asia, Cambridge University Press, Cambridge.

Iheduru, O.C., 2008, 'Why Anglo licks ANC's boots: Globalization and state capital relations in South Africa', African Affairs 107(428), 333-360. https://doi. org/10.1093/afraf/adn037

Iwuagwu, O., 2009, 'Nigeria and the challenge of industrial development: The new cluster strategy', African Economic History 37(1), 151-180.

Jesudason, J.V., 1990, Ethnicity and the economy: The Chinese businesses and multinationals in Malaysia, Oxford University Press, Oxford.

Kaplan, E.J., 1972, Japan: The government and business relationship: A guide for American Businessman, U.S. Department of Commerce, Washington, DC.

Kenton Will, 2018, Unbundling.
Khehla, S. \& Reddy, C., 2007, Empowerment and its critics, Business Map Foundation, Johannesburg.

Kilambo, S.R., 2016, 'Black economic empowerment and change in ownership and control in South Africa's mining industry', PhD thesis, University of Edinburgh, Edinburgh.

KIO Advisory Services, 2010, 'Management control and employment equity in the mining industry: Draft report for Public Comment 2010', South African Mining Development Association, Johannesburg.

Lall, S., 1996, Learning from the Asian Tigers: Studies in technology and industria policy, MacMillan Press, London.

Lonmin Plc, 2010 and 2011, Annual report and accounts, Lonmin, Johannesburg.

Makgoba, M., 2019, 'Constructing black economic empowerment transactions in South African mining: Government v corporate discourse', African Studies 78(4), 568-589. https://doi.org/10.1080/00020184.2019.1578167

Malherbe, S. \& Segal, N., 2001, Corporate governance in South Africa, Trade and Industrial Policy Strategies Annual Forum, Pretoria.

Mandla, B., 2006, 'BEE and Malaysia NEP: A comparative study', MA dissertation, University of Stellenbosch, Stellenbosch.

Marais, H., 2011, South Africa pushed to the limit. The political economy of change, University of Cape Town Press, Cape Town.

Mathe, H., 2008, 'BEE economics and its influence on growth of the new South Africa', Mine Africa BEE seminar, July, Johannesburg.

Mbeki, T., 1999, 'Challenge of the formation of a black capitalist class, a black bourgeoisie', Speech at the annual national conference of the black management forum, Kempton Park, 20 November, viewed 23 April 2018, from https://www. mbeki.org/2016/06/09/speech-at-the-annual-national-conference-of-the-blackmanagement-forum-kempton-park-19991120/.

Mbeki, T., 2003, State of the nation address, viewed 23 April 2018, from https://www. gov.za/state-nation-address-president-south-africa-thabo-mbeki-housesparliament-cape-town-14-february-2003\#.

Mbeki, M., 2007, Is BEE working? viewed 05 March 2009, from http://allafrica.com/ stories/200703231106.html.

Mtongana, L., 2016, 'Exxaro in an eskom hole over BEE', Sunday Times/Business Times, 04 December, p. 4

Mtongana, L., 2018, 'DMR seeks to sort out the past to ensure future works better', Sunday Times/Business News, 29 April, p. 5.

Nattrass, N., 1981, The South African economy: Its growth and change, Oxford University Press, Oxford.

Nhasengo, A., 2016, 'Sustainability of funding models in black economic empowerment transactions in South Africa's mining sector', MSc dissertation, University of the Witwatersrand, Johannesburg.

Ndongko, W.A., 1980, 'Indigenisation policy and the development of private enterprise in Nigeria', African Spectrum 15(1), 53-71.

Northam, 2011, Northam circular to shareholders, Northam, Johannesburg.

Northam Platinum Ltd., 2010, Annual report, Northam, Johannesburg.

Optimum Coal, 2009, 2010, Annual report, Optimum Coal, Johannesburg.

Palabora Mining Company Limited, 2010a, Integrated annual report, Palabora Mining, Johannesburg.

Palabora Mining Company Limited, 2010b, Sustainable development report, Palabora Mining, Johannesburg.

Picketty, T., 2010, 'On the long-run evolution of inheritance: France 1820-2050', Working Papers, September 3rd 2010, Paris School of Economics, Paris.

Public Protector, 2016, State capture report 2016, Public Protector, Pretoria

Rajak, D., 2012, 'Platinum city and the new South African dream', Africa 82(2), 252-271. https://doi.org/10.1017/S0001972012000046

Republic of South Africa, 2002a, Score card for the broad based socio-economic empowerment charter for the South African Mining Industry, South African Government, Pretoria.

Republic of South Africa, 2002b, The Minerals and Petroleum Resources Development Act, South African Government, Pretoria.

Republic of South Africa, 2004, The broad-based socio economic empowerment charter for the South African mining sector, Government Gazette No. 2666, 13/8/2004.

Research Channel Africa, 2006, Black economic empowerment in mining, Creamer Media, Johannesburg.

Research Channel Africa, 2008, Black economic empowerment in mining, Creamer Media, Johannesburg.

Rhee, C., 1994, The state and industry in South Korea: Limits of authoritarian state, Routledge, London.

Richards Bay Minerals, 2011, Annual report, RBM, Johannesburg.

Richards Bay Minerals, 2012, Annual report, RBM, Johannesburg.

Seidman, A. \& Seidman, N., 1977, US multinationals in Southern Africa, Tanzania Publishing House, Dar Es Salaam.

Segeant, B., 2006, Brett Kebble: The inside story, Zebra Press, Johannesburg. 
Southall, R., 2007, 'Ten propositions about black economic empowerment in South Africa', Review of African Political Economy 34(111), 67-84. https://doi. org/10.1080/03056240701340365

Sowel, T., 2004, Affirmative action around the world, Donnelley and Sons, New York.

Taylor, S.D., 2007, Business and the state in Southern Africa: The politics of economic reform, Lynne Rienner Publishers, London.
Treasury, 2017, Ownership of JSE-listed companies, Research Report, National Treasury, Pretoria.

Treasury, 2018, Mid-term budget review, 24 October, National Treasury, Pretoria.

Villa, S., 2013, 'Ramaphosa's controversial swiss partner', Sunday Times/Business Times, 22 December, p. 9

Wesizwe Platinum, 2011, Annual report, Johannesburg. 